universal time, and this is incompatible with special relativity.

Dingle believed that his question concerning clock-rates was not answered but evaded by his critics. In his struggle with what he came to regard as the 'relativistic establishment', described in his book Science at the Crossroads (1972), he was often treated in a way that convinced him that truth was being sacrificed to dogma. His attitude towards relativistic physics was not, however, purely negative, for he adopted, and spent much time in developing, the alternative 'ballistic' theory of light-transmission due to W. Ritz.

Despite his criticism of special relativity, Dingle never lost his respect for Einstein's genius, just as he no less admired his fellow quaker Eddington despite submitting the latter's philosophy of physics to devastating criticism in his brilliant Eddington Memorial Lecture on The sources of Eddington's philosophy (1954).

No obituary notice of Dingle should fail to mention the beautiful literary style that graced all he wrote. He had a deep knowledge and appreciation of English literature, particularly poetry. Two of his books were on Science and literary criticism (1949) and The mind of Emily Brontë (1974). His friends will long remember his lively conversation spiced with a rapier-like wit and numerous anecdotes, and his many acts of kindness, not least to those refugees from Europe whom he and his wife so generously assisted in the nineteenthirties.

G. J. Whitrow

\section{M.H.L. Pirenne}

Maurice Henri Léonard Pirenne, well known for his work in the physiology of vision, died in Oxford on 11 Octoher 1978.

Maurice Pirenne was born in Verviers, Belgium in 1912. $\mathrm{He}$ graduated DrSc at Liège, and spent the next year doing research in molecular physics with Professor Debye. The following three years were spent at Columbia University, New York, with Selig Hecht studying the biophysics of vision, and it was probably this period, more than any other, that determined his future interests.

In 1942, a classical paper by Hecht, Shlaer and Pirenne demonstrated that the uncertainty of seeing near the visual threshold, usually attributed to biological variation, was in fact largely accounted for by purely physical variations in the small number of light quanta absorbed by the visual photopigment. Much of Pirenne's later work was concerned with the visual threshold and its relationship to visual acuity, ranging in scope from the practical problem of screening servicemen for night blindness, to neurophysiological studies of the thresholds of 'on' and 'off' units and their interaction.

He returned to England in 1941 and worked in Cambridge, London and Aberdeen before joining the University Laboratory of Physiology, Oxford, in 1955. He became a fellow of Wolfson College, and worked in Oxford until his retirement. As a teacher, he will be remembered particularly for his demonstrations and class work. The experiments that brought the subject so vividly to life were based upon long hours of preparation and adjustment.

Maurice Pirenne was the son of an artist, and while he was still at school his father encouraged him to read the work of Brücke and Helmholtz on vision and art. His interest in drawing and painting lasted all his life, and in recent years he had returned to the study of the relationship between visual physiology and the perception of pictures. Optics, Painting and Photography (1970) is concerned mainly with perspective, and how far a painting in perspective can really look convincing to an observer who, instead of viewing it with one eye placed in the ideal position, uses both eyes and moves to different positions. His last publication, in 1975, was on Vision and Art.

All Pirenne's scientific work was characterised by acute commonsense and painstaking accuracy. The same qualities appear in his published work. Vision and the Eye, which first appeared in 1948 remains the clearest and most readable introduction to the subject. He was internationally recognised as an authority on visual physiology, and in 1972 received an ScD at Cambridge and was appointed a Foreign Member of the Royal Belgian Academy of Sciences.

$$
\text { F. H. C. Marriott }
$$

\section{B. B. Roberts}

Brian Birley Roberts, authority on polar problems and ornithologist, died in Cambridge on 9 October 1978 at the age of 65 . For thirty years Head of the Polar Regions Section, Foreign and Commonwealth Office, he was also a Research Fellow at the Scott Polar Research Institute, Cambridge and a Fellow of Churchill College.

His interests in the polar regions started when he was still a schoolboy and he became probably the foremost specialist in the world. As an undergraduate at Emmanuel College, Cambridge, he led expeditions to Iceland and East Greenland in 1932 and 1933 and later joined the British Grahamland Expedition (1934-1937). As an ornithologist, he will be particularly remembered for his paper on Wilson's petrel published in 1940, which has stood the test of time as a good and careful study. It dealt with breeding behaviour, growth and reproductive success; the remarkably long annual migration was illustrated by monthly distribution maps and supported by ringing returns, which proved that individuals return each year to the same mate and burrow in the Antarctic.

In 1940 he took a Cambridge PhD and was awarded the Polar Medal and the Bruce Memorial Prize of the Royal Society of Edinburgh. He received the Back Award of the Royal Geographical Society in 1948. During the war years he served in Naval Intelligence and advised the War Office on cold climate equipment. He revisited the Antarctic in $1950-51,1960-61,1964,1972$ and finally in 1976, shortly after his retirement.

Brian Roberts played a formative role in discussions leading to the Antarctic Treaty (1959) which ensured the continuance of the freedom of scientific investigation and the free exchange of results which marked the International Geophysical Year 19571958. He did much to promote the Agreed Measures for the Conservation of Antarctic Flora and Fauna (1964) and the Convention for the Conservation of Antarctic Seals (1972). While he asserted that he had had to eat more seals than any others present, he was dedicated to conservation and also regarded that convention as the forerunner of a broader convention dealing with other Antarctic marine living resources, especially krill, now being negotiated. Although often the only scientist in a group of diplomats and lawyers, it was to Brian Roberts that they frequently turned for help in resolving a diplomatic impasse.

$\mathrm{He}$ played an active role in the formation of the British Antarctic Survey and he had an enduring influence on the development of the library of the Scott Polar Research Institute and the establishment of what developed into the International Glaciological Society. He was a leading expert on Antarctic history, terminology and place names.

He was made CMG in 1969 and in 1976 was awarded the Founder's Medal of the Royal Geographical Society. He was president of the Antarctic Club in 1963 and of the Arctic Club in 1973.

Many senior polar scientists benefited, as young research workers and later, from the stimulation of his presence, his phenomenal range of detailed knowledge and constructive criticism. His beaming smile, kindness, wit, scholarship, experience and great capacity for work will be long remembered by his many friends, who will find it difficult to believe he is no longer there. 